\title{
A study of Heavy Metal Pollution in Groundwater of Malwa Region of Punjab, India: Current Status, Pollution and its Potential Health Risk
}

\author{
Rajni Sharma ${ }^{1}$, Dr. Ashit Dutta ${ }^{2}$ \\ ${ }^{1}$ Bhagwant University, Ajmer (Rajasthan) \\ ${ }^{2}$ Department of Applied Science, Bhagwant University, Ajmer Bhagwant University, Ajmer
}

\section{ABSTRACT}

Among the different types of pollution, heavy metal pollution has become one of the major environmental issues in India. A number of studies show that high level of heavy metal exposure is a frequent cause of permanent intellectual and developmental disabilities. In this present study, the AAS method is used to determine the various heavy metal concentrations for 240 samples of Groundwater distributed in eight districts in Malwa Region of Punjab. The concentration values were compared with Standard Values given by BIS. The results showed that the maximum percentage of groundwater samples of Malwa region is beyond the permissible limits and that's why not fit for drinking purposes and other domestic activities due to the presence of various heavy metals . The overall groundwater quality of Punjab for Arsenic, lead, Iron, Cobalt, Chromium, zinc and Mercury can also be detected and compared with BIS standards. The aim of this particular study was to investigate the distribution of Heavy metals in groundwater of Malwa Region of Punjab and its greater risks to public health. The results were compared with the recommended standards for drinking water of BIS to know the existing status and trend. Overall, water quality was found as unsatisfactory for drinking purposes in all the samples.

Keywords: Heavy Metal pollution, Groundwater, Human Health, BIS Guidelines, Malwa Region, Punjab.
\end{abstract}

\section{INTRODUCTION}

Heavy metal pollution is an inorganic chemical hazard, which is mainly caused by lead $(\mathrm{Pb})$, chromium $(\mathrm{Cr})$, arsenic $(\mathrm{As})$, cadmium $(\mathrm{Cd})$, mercury $(\mathrm{Hg})$, Zinc $(\mathrm{Zn})$, copper $(\mathrm{Cu})$, cobalt $(\mathrm{Co})$ and nickel (Ni) (Jarup, L., 2003). Five metals among them, $\mathrm{Pb}, \mathrm{Cr}$, $\mathrm{As}, \mathrm{Cd}$ and $\mathrm{Hg}$, are the key heavy metal pollutants in Malwa region of Punjab. These heavy metals are classified as strong carcinogens by the International Agency for Research on Cancer (Sarkar, B., 2002). High level of heavy metal exposure can also cause permanent intellectual and developmental disabilities, including reading and learning disabilities, behavioral problems, hearing loss, attention problems, and disruption in the development of visual and motor function (Sarkar, B., 2002). So, it is important to know the quality of groundwater because it is the major factor which decides its suitability for domestic, agriculture and industrial purposes (Raju, Ram, \& Dey,2009). The suitability of groundwater for drinking and other purposes may be assessed by comparing heavy metal concentrations of the study area with the guidelines recommended by Bureau of Indian Standards (BIS, 2012). The existence of heavy metals in the groundwater of the Malwa region has been proven by earlier studies. Their origin can be traced back both to natural weathering and to discharges from mining and industrial activities in the region. Due to the toxic nature of Heavy metals there are reasons to survey the presence of metals in the area.

\section{MATERIAL AND METHODS}

PUNJAB: The state of Punjab located in North West India, bordering Pakistan, extends from $29^{\circ} 32^{\prime}$ to $32^{\circ} 32^{\prime}$ North and $73^{\circ} 55^{\prime}$ to $76^{\circ} 50^{\prime}$ East. It is surrounded by the Indian states of Jammu and Kashmir in the north; the hilly state of Himachal Pradesh in the east; and by the state of Haryana and Rajasthan in the south. It covers a geographical area of 50,362 square kilometers and is one of the smallest states in India.

STUDY AREA: The study area comprises of eight districts of the Malwa region in Punjab namely, Sangrur, Barnala, Moga, Firozpur, Faridkot, Muktsar, Bathinda and Mansa. The entire study area lies between latitudes of $29^{\circ} 32^{\prime} 19^{\prime \prime}$ and $31^{\circ}$ $10^{\prime} 58^{\prime \prime}$ North, and longitudes of $73^{\circ} 52^{\prime} 33^{\prime \prime}$ and $76^{\circ}$ 12 ' 40 " East. The study area covers 22.175 square kilometres out of a total of 50.362 square kilometres area in the state. It includes 2102 villages out of 12959 villages of Punjab. The study area covers 44 percent of the area of the state, though it covers only 16 percent of the villages. This is because villages in Malwa region, where the study area is located, are much larger in size than the villages in the rest of the state. 


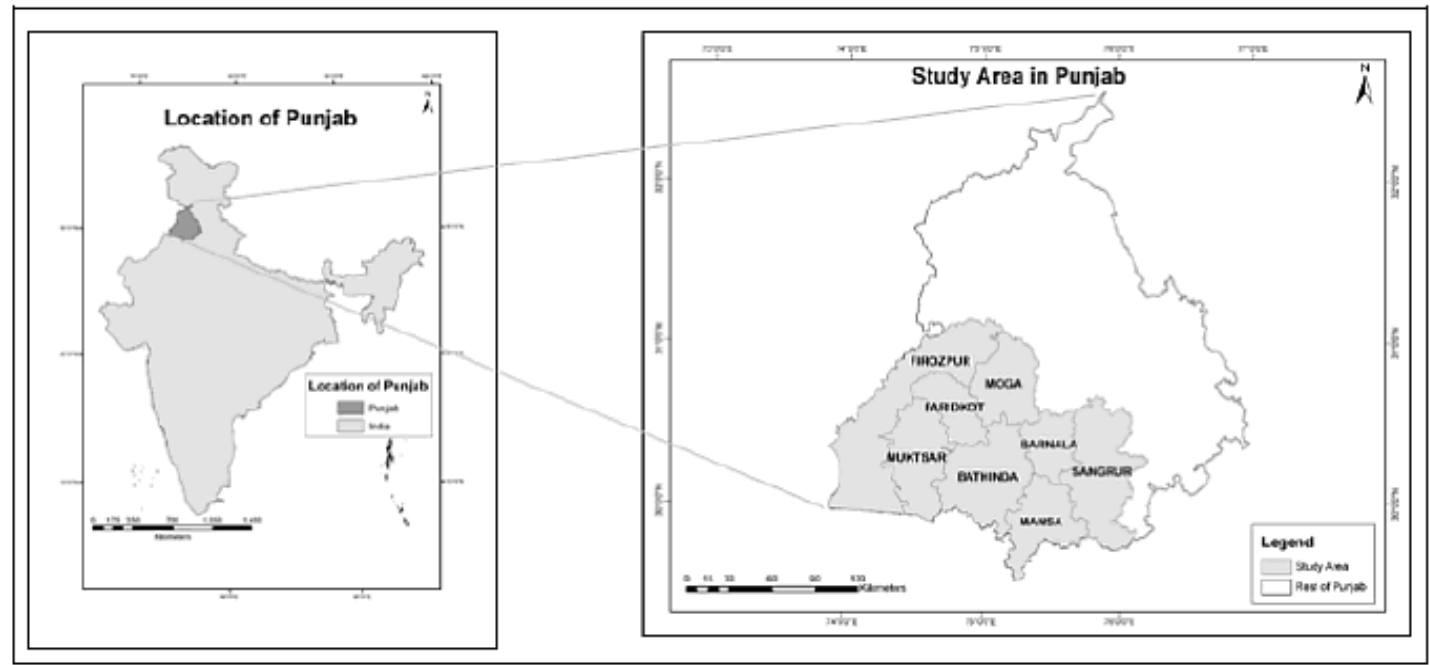

Figure 1: Location of the state of Punjab (left) and study area (right) comprising of eight districts in the Malwa region.

Overall 240 groundwater sources (locations) showing distribution as 61 from Bathinda, 36 from Muktsar, 33 from Ferozpur, 14 from Faridkot, 48 from Moga, 28 from Mansa, 10 from Barnala and 10 from Sangrur in 8 districts of Malwa Punjab were selected for monitoring from where the people are getting water mainly for drinking purposes. All these water samples were taken from hand pump.

\section{SAMPLE COLLECTION}

Field work began immediately after the identification of 240 villages in the study area from a period of May 2010 to May2012. Borosilicate glassware, distilled water and E-Merk reagents were used throughout the experiment. Samples were collected in pre sterilized screw-capped polythene bottles of five liter capacity, were properly labeled, record was prepared and analyzed in laboratory for their physico-chemical parameters. Water samples were stored at $4^{\circ} \mathrm{C}$ till further analysis of the next samples. Parameters were analyzed by standard methods (APHA, AWWA, WEF, 1998).

Analytical Procedures

The groundwater samples were analyzed for heavy metals parameters by using atomic absorption spectrophotometry. The analytical data quality was ensured through careful standardization, procedural blank measurements and duplicate samples.

$100 \mathrm{ml}$ aliquot of filtered water sample was taken in duplicate for wet digestion $\left(\mathrm{HNO}_{3}\right)$ on hot plates to destroy organic material in the sample. $25 \mathrm{ml}$ of the prepared sample was injected in the nebulizerspray chamber-burner system of the Atomic Absorption Spectrophotometer. Air-acetylene compressed gas has been used as oxidant and fuel. Atomic Absorption Spectrophotometer was standardized with standard element concentrations in prior.

\section{RESULTS AND DISCUSSION}

Heavy metals data along with the statistical measures such as average, maximum and minimum for the ground water are discussed below:

\section{-Lead (Pb)}

Lead is one of the most abundant heavy metals in nature. Figure 2 showing the lead distribution in the area. Basic statics is shown by Table 1. Lead concentration beyond the $0.01 \mathrm{mg} / \mathrm{l}$ leads to hazardous effects as recommended desirable level (BIS, 2004-05). Study predicts $91 \%$ samples violation in respect of limit. Its presentation may be due to Industrial effluents, which are regularly discharged in surface water without any prior treatment or improper treatment. During monsoon season lead compound and other compounds leached to the groundwater (CPCB, 2001). Long time contact of supply water with lead made pipes may be the lead occurrence in tap water (Jain et al., 2010). Mentally-physically disabilities, low learning capability-development rate are the effects of lead toxicity in water (USEPA, 2004). 
Table 1: Status of Lead in the Drinking Water of Malwa Region of Punjab

\begin{tabular}{|c|c|c|c|c|c|c|c|}
\hline S.No & Districts & $\begin{array}{c}\text { Total } \\
\text { Samples }\end{array}$ & $\begin{array}{c}\text { No. of Unsafe } \\
\text { Samples }\end{array}$ & $\begin{array}{c}\text { \%age of Unsafe } \\
\text { Samples }\end{array}$ & Minimum & Maximum & Average \\
\hline 1 & Bathinda & 61 & 47 & 77 & 0.001 & 28.04 & 15.11 \\
\hline 2 & Muktsar & 36 & 36 & 100 & 0.97 & 1.98 & 1.55 \\
\hline 3 & Faridkot & 14 & 14 & 100 & 12 & 17.8 & 14.62 \\
\hline 4 & Ferozpur & 33 & 33 & 100 & 11.5 & 18.4 & 14.73 \\
\hline 5 & Moga & 48 & 48 & 100 & 0.03 & 1.99 & 1.07 \\
\hline 6 & Mansa & 28 & 28 & 100 & 12 & 22 & 15.22 \\
\hline 7 & Barnala & 10 & 7 & 70 & 0.009 & 0.027 & 0.019 \\
\hline 8 & Sangrur & 10 & 6 & 60 & ND & 0.027 & 0.014 \\
\hline & Total & $\mathbf{2 4 0}$ & $\mathbf{2 1 9}$ & $\mathbf{9 1}$ & ND & $\mathbf{2 8 . 0 4}$ & $\mathbf{7 . 7 9}$ \\
\hline
\end{tabular}

In the study area, the minimum and maximum concentrations of lead lies between $0.001 \mathrm{mg} / \mathrm{l}$ to $28.04 \mathrm{mg} / \mathrm{l}$, with an average of $7.79 \mathrm{mg} / \mathrm{l}$. According to BIS guidelines, the desirable and maximum permissible limit of lead in drinking water is $0.01 \mathrm{mg} / \mathrm{l}$. Beyond this limit it causes health hazardous to human health. The maximum concentration of lead was found at
Bathinda $(28.04 \mathrm{mg} / \mathrm{l})$ followed by Mansa $(22.0 \mathrm{mg} / \mathrm{l})>$ Ferozpur $(18.4 \mathrm{mg} / \mathrm{l})>$ Faridkot $(17.8 \mathrm{mg} / \mathrm{l})>$ Moga $(1.99 \mathrm{mg} / \mathrm{l})>$ Muktsar $(1.98 \mathrm{mg} / \mathrm{l}) \quad$ while lowest concentration was recorded at Barnala and Sangrur $(0.027 \mathrm{mg} / \mathrm{l})$ as shown in Figure 2.

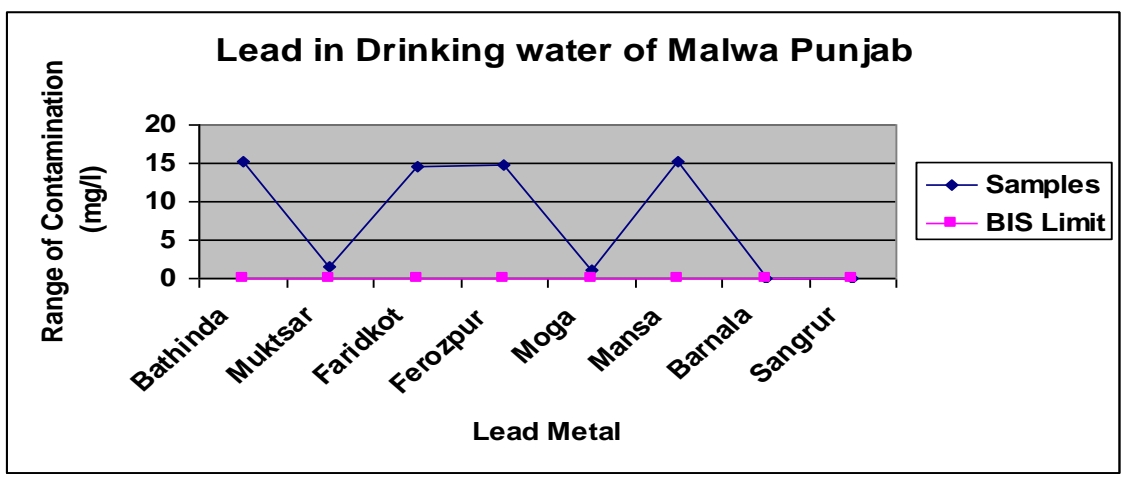

Figure 2: Lead Contamination in Malwa Punjab

\section{-Arsenic (As)}

Arsenic is widely distributed in the environment because of its natural and anthropogenic sources (Hundal,2009). Arsenic is the $20^{\text {th }}$ most abundant element found naturally in the Earth's crust. In very small quantities, it plays an essential role in animal metabolism but in large amounts it is damaging due to its carcinogenicity (Pickering et al.,2000). Arsenic is a heavy metal that can cause significant health problems by primarily attacking the immune system (Huang et al., 2004). In surface and groundwater, arsenic is found dissolved in inorganic form (arsenite, arsenic) and organic form (acid-monimetilarsonic MMA-DMA dimetilarsenic acid). Inorganic arsenic is know to have high levels of toxicity. When arsenic is ingested, it also increases the risk of bladder and prostrate cancers. It can also cause other health disorders such as a decrease in hearning ability,skin thickening and disturbances to the nervous system. Drinking water contaminated with unsafe levels of arsenic may cause cancer of the skin, bladder,lungs and possibly other internal organs and noncancerous effects (diabetes mellitus, nodular keratosis) including manifestations that are indicative of chronic arsenic poisoning (Nimick, 1994; Focazioetal, 1999). Analytical results show that excessive arsenic concentration present in Ferozpur (85\%), Bathinda $(80 \%)$ and Muktsar $(72 \%)$ districts if we follow BIS guideline value of $0.05 \mathrm{mg} / 1$ as standard. Range of arsenic concentration (minimum and maximum) in all the districts is shown as Table 2 . For the first time, eight districts having different parameters were determined under this project by using high tech state of art instrument viz. Atomic Absorption Spectrophotometer. It has also been observed that deep groundwater sources have been found generally free from bacteria may be due to least seepage influence. However, groundwater sources/locations have been found more contaminated lying in the dense population areas. 
A different pattern of results presentation is adopted on district level basis instead of parameters, which is more appropriate and easy in understanding for policy makers, district municipal community and water supply managers to adopt future line of actions.

In the present study, the concentration of arsenic ranged from 0.002 and $12 \mathrm{mg} / \mathrm{L}$ with an average of $1.03 \mathrm{mg} / \mathrm{l}$. Maximum concentration of arsenic were recorded at Mansa $(12 \mathrm{mg} / \mathrm{l})$ followed by Ferozpur $(2.92 \mathrm{mg} / \mathrm{l})>$ Faridkot $(2.8 \mathrm{mg} / \mathrm{l})>$ Moga $(1.98 \mathrm{mg} / \mathrm{l})>$ Muktsar $(1.84 \mathrm{mg} / \mathrm{l})>$ Bathinda $(1.82 \mathrm{mg} / \mathrm{l})>$ Sangrur $(0.076 \mathrm{mg} / \mathrm{l})$ while lowest concentrations recorded at Barnala $(0.069 \mathrm{mg} / \mathrm{l})$. The maximum acceptable level of arsenic is 0.05 $\mathrm{mg} / \mathrm{l}$ (BIS,1991). Maximum parts of India suffer from arsenic contamination of the groundwater, with natural geological reasons as the primary cause. The damaging effects of arsenic on health are widely ranging from arsenic poisoning linked to neurological, dermatological and gastrointestinal problems (Hughes, 2002) to various kind of cancers (U.S.Environmental Protection Agency,1999). Several other studies reported that chronic intakes of about $10 \mu \mathrm{g} / \mathrm{Kg}$ body wt/day or higher values may result in dermatological and other signs of arsenic toxicity (Hindmarsh et al., 1977; Cerbrian et al., 1983; Chakraborty and Saha, 1987; Abernathy et al., 1989; Roychowdhury et al., 2002b; Rahman et al., 2003; Roychowdhury, 2008a).

Measurable concentrations of the metal were found in all samples of eight district exceeded the maximum contaminant limits as per BIS drinking water. According to BIS guidelines, the desirable and maximum permissible limits for arsenic are $0.01 \mathrm{mg} / \mathrm{l}$ and $0.05 \mathrm{mg} / \mathrm{l}$. The concentration levels of Arsenic in all the samples are shown in Table 2 and the comparison levels of Arsenic in study area is shown in Figure 3.

Table 2: Status of Arsenic in the Drinking Water of Malwa Region of Punjab.

\begin{tabular}{|c|c|c|c|c|c|c|c|}
\hline S.No & Districts & $\begin{array}{c}\text { Total } \\
\text { Samples }\end{array}$ & $\begin{array}{c}\text { No. of Unsafe } \\
\text { Samples }\end{array}$ & $\begin{array}{c}\text { \%age of Unsafe } \\
\text { Samples }\end{array}$ & Minimum & Maximum & Average \\
\hline 1 & Bathinda & 61 & 49 & 80 & 0.02 & 1.82 & 1.28 \\
\hline 2 & Muktsar & 36 & 26 & 72 & 0.02 & 1.84 & 1.25 \\
\hline 3 & Faridkot & 14 & 10 & 71 & 0.02 & 2.8 & 1.35 \\
\hline 4 & Ferozpur & 33 & 28 & 85 & 0.002 & 2.92 & 1.16 \\
\hline 5 & Moga & 48 & 32 & 67 & 0.002 & 1.98 & 0.99 \\
\hline 6 & Mansa & 28 & 11 & 39 & ND & 12 & 2.13 \\
\hline 7 & Barnala & 10 & 4 & 40 & 0.0037 & 0.069 & 0.03 \\
\hline 8 & Sangrur & 10 & 3 & 30 & 0.027 & 0.076 & 0.03 \\
\hline & Total & $\mathbf{2 4 0}$ & $\mathbf{1 6 1}$ & $\mathbf{6 7}$ & $\mathbf{N D}$ & $\mathbf{1 2}$ & $\mathbf{1 . 0 3}$ \\
\hline
\end{tabular}

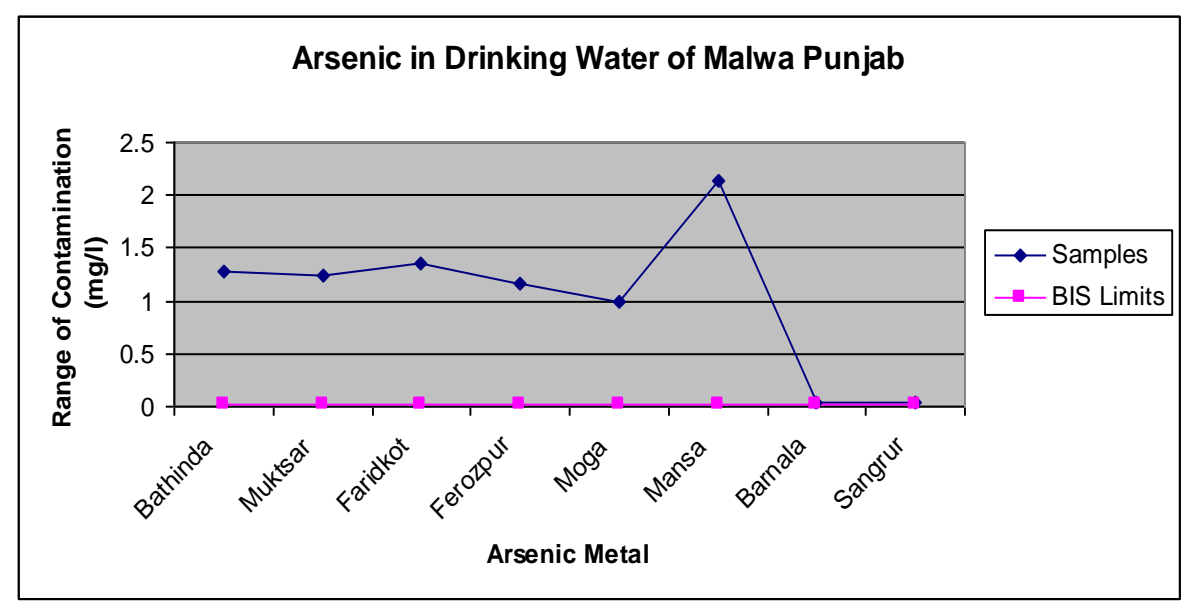

Figure 3: Arsenic Contamination in Malwa Punjab

-Iron (Fe)

Iron in the study area shows 0.026-7.6 with an average of $0.54 \mathrm{mg} / \mathrm{l}$ (Figure 36). Iron in groundwater may be very harmful for any kind of domestic purposes. BIS recommended the desirable-permissible limit for Iron in drinking water as 0.3 and $1.0 \mathrm{mg} / \mathrm{l}$. Violation with respect to permissible level were recorded in $38 \%$ samples. Change in the colour of groundwater is the indication of iron presence, moreover higher concentration leading to astringent, bitter inky taste of the water. Encrusting of water supply pipes due 
to scaling, Fixtures plumbing, discoloring of the clothes are the other hazardous effect occur due to iron contamination (Jain et al., 2010). Major anthropogenic sources in groundwater are steel industry waste and other alloy containing iron as constituent (Christensen et al., 2001) which is supposed to be the result of discharging-dumping waste effluent without treatment (European
Commission Report, 2002). Iron may be released in groundwater as results of various reductionoxidations, ion-exchange-physico-chemical process (Drever, 1997). The minimum and maximum concentrations of Iron were 0.026 to $7.6 \mathrm{mg} / \mathrm{L}$ respectively. Whereas the maximum allowable limit for Iron as per BIS guidelines is $0.3 \mathrm{mg} / \mathrm{L}$.

Table 3: Status of Iron in the Drinking Water of Malwa Region of Punjab

\begin{tabular}{|c|c|c|c|c|c|c|c|}
\hline S.No & Districts & $\begin{array}{c}\text { Total } \\
\text { Samples }\end{array}$ & $\begin{array}{c}\text { No. of Unsafe } \\
\text { Samples }\end{array}$ & $\begin{array}{c}\text { \%age of Unsafe } \\
\text { Samples }\end{array}$ & Minimum & Maximum & Average \\
\hline 1 & Bathinda & 61 & 17 & 28 & ND & 1.8 & 0.4 \\
\hline 2 & Muktsar & 36 & 3 & 8 & 0.05 & 0.37 & 0.14 \\
\hline 3 & Faridkot & 14 & 7 & 50 & ND & 0.53 & 0.15 \\
\hline 4 & Ferozpur & 33 & 33 & 100 & 0.97 & 1.9 & 1.52 \\
\hline 5 & Moga & 48 & 19 & 40 & 0.039 & 7.6 & 1.03 \\
\hline 6 & Mansa & 28 & 7 & 25 & 0.026 & 1.8 & 0.45 \\
\hline 7 & Barnala & 10 & 6 & 60 & 0.1 & 0.58 & 0.32 \\
\hline 8 & Sangrur & 10 & 6 & 60 & 0.27 & 0.38 & 0.31 \\
\hline & Total & $\mathbf{2 4 0}$ & $\mathbf{9 8}$ & $\mathbf{4 1}$ & ND & $\mathbf{7 . 6}$ & $\mathbf{0 . 5 4}$ \\
\hline
\end{tabular}

In the study area, the minimum and maximum concentrations of Iron were 0.026 to 7.6 $\mathrm{mg} / \mathrm{L}$, with an average of $0.54 \mathrm{mg} / \mathrm{l}$ respectively. Whereas the maximum allowable limit for Iron as per BIS guidelines is $0.3 \mathrm{mg} / \mathrm{L}$. The maximum concentration of iron was recorded at Moga (7.6 $\mathrm{mg} / \mathrm{l})$ followed by Ferozpur $(1.9 \mathrm{mg} / \mathrm{l})>$ Bathinda, Mansa $(1.8 \mathrm{mg} / \mathrm{l})>$ Barnala $(0.58 \mathrm{mg} / \mathrm{l})>$ Faridkot $(0.53 \mathrm{mg} / \mathrm{l})>$ Sangrur $(0.38 \mathrm{mg} / \mathrm{l})$ while lowest iron concentration was found at Muktsar $(0.37 \mathrm{mg} / \mathrm{l})$. Iron is an abundant metal found in the Earth's crust. It is naturally present in water but can also be present in drinking water from the use of iron coagulants or the corrosion of steel and cast iron pipes during water distribution. Iron is an essential element in human nutrition. The WHO (WHO, 2004) states that values of up to $2 \mathrm{mg} / \mathrm{l}$ (10 times the parametric value) do not present a hazard to health. However, at levels less than $2 \mathrm{mg} / \mathrm{l}$ but above the parametric value, the colour of water may turn brown, become turbid or may deposit solids on clothes washed in the water or food cooked using water.

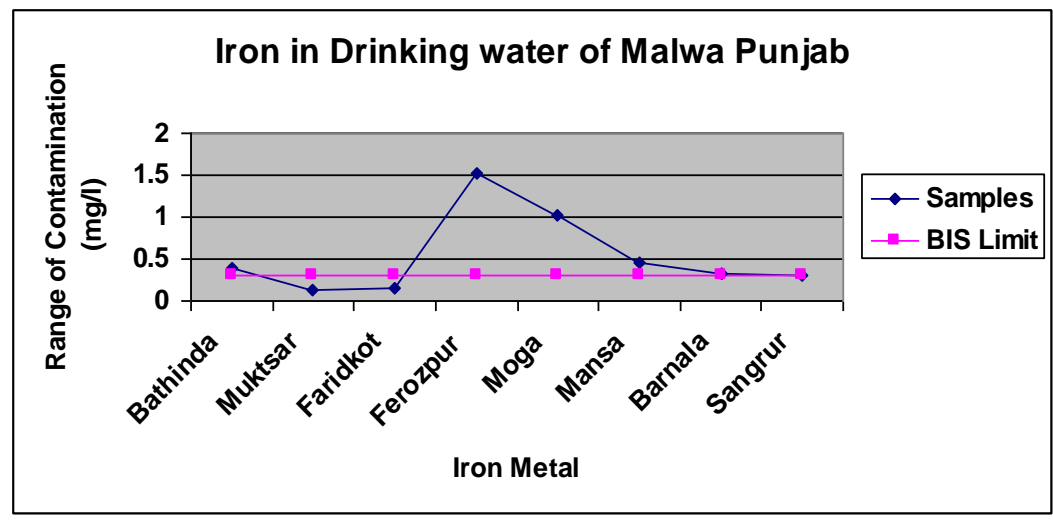

Figure 4: Iron Contamination in Malwa Punjab

\section{-Cadmium (Cd)}

Cadmium is omnipresent element, not only because of its nature, but also due to its several anthropogenic sources, mainly coming from its large application in industrial fields. The minimum and maximum concentrations of Cadmium were 0.001 to $2.9 \mathrm{mg} / \mathrm{L}$ respectively.
Whereas the maximum allowable limit for cadmium as per BIS guidelines is $0.003 \mathrm{mg} / \mathrm{L}$. Maximum concentration was recorded at Ferozpur $(2.9 \mathrm{mg} / \mathrm{l})$ followed by Faridkot $(0.022 \mathrm{mg} / \mathrm{l})>$ Muktsar, Moga and Mansa $(0.009 \mathrm{mg} / \mathrm{l})>$ Barnala and Sangrur $(0.008 \mathrm{mg} / \mathrm{l})$ while lowest value found at Bathinda $(0.006 \mathrm{mg} / \mathrm{l})$. Cadmium concentration 
levels in all studied samples are exceeding then compared BIS Standards. The concentration levels of cadmium in all the samples are shown in table 4 and the comparison levels of cadmium in study area is shown in Figure 5.

Table 4: Status of Cadmium in the Drinking Water of Malwa Region of Punjab

\begin{tabular}{|c|c|c|c|c|c|c|c|}
\hline S.No. & Districts & $\begin{array}{c}\text { Total } \\
\text { Samples }\end{array}$ & $\begin{array}{c}\text { No. of Unsafe } \\
\text { Samples }\end{array}$ & $\begin{array}{c}\text { \%age of Unsafe } \\
\text { Samples }\end{array}$ & Minimum & Maximum & Average \\
\hline 1 & Bathinda & 61 & 40 & 66 & 0.001 & 0.006 & 0.013 \\
\hline 2 & Muktsar & 36 & 23 & 64 & 0.001 & 0.009 & 0.004 \\
\hline 3 & Faridkot & 14 & 9 & 64 & 0.001 & 0.022 & 0.006 \\
\hline 4 & Ferozpur & 33 & 25 & 76 & 1.43 & 2.9 & 0.005 \\
\hline 5 & Moga & 48 & 19 & 40 & 0.001 & 0.009 & 0.004 \\
\hline 6 & Mansa & 28 & 22 & 79 & 0.001 & 0.009 & 0.005 \\
\hline 7 & Barnala & 10 & 7 & 70 & 0.001 & 0.008 & 0.005 \\
\hline 8 & Sangrur & 10 & 7 & 70 & 0.001 & 0.008 & 0.005 \\
\hline & Total & $\mathbf{2 4 0}$ & $\mathbf{1 5 2}$ & $\mathbf{6 3}$ & $\mathbf{0 . 0 0 1}$ & $\mathbf{2 . 9}$ & $\mathbf{0 . 0 0 5 8 7 5}$ \\
\hline
\end{tabular}

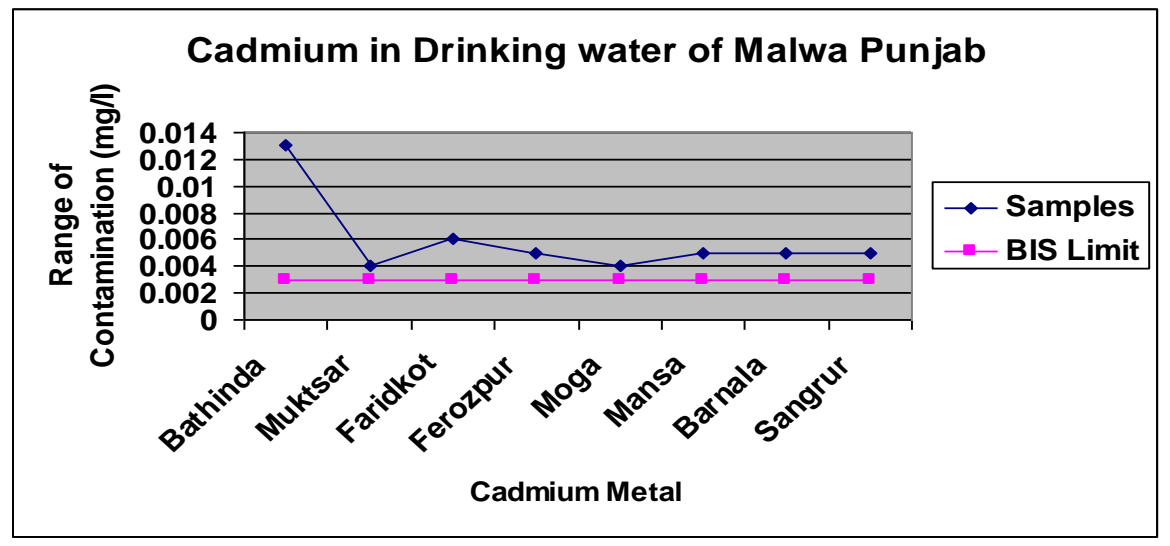

Figure 5: Cadmium Contamination in Malwa Punjab

\section{-Chromium (Cr)}

Chromium is found naturally in rocks, plants, soil and volcanic dust, humans and animals and anthropogenic sources of $\mathrm{Cr}^{6+}$ in drinking water are discharges from steel and pulp mills, and erosion of natural deposits of $\mathrm{Cr}^{3+}$ (EPA, 2007). Chromium is an important industrial metal used in diverse products and processes (Nriagu, 1988).At many locations, chromium has been released into the environment via leakage, poor storage or improper disposal practices (Palmer and Wittbrodt, 1991; Calder, 1988). Chromium is an essential trace element involved in stimulation of enzymes, peripheral action of insulin, lipid metabolism and possibly in the stabilization of nucleic acids (Anderson et al., 1983, Anderson et al., 1998, Vincent et al., 2000) Trivalent chromium occurs naturally in rocks, soil, plants, animals and volcanic emissions. Chromium is used in the manufacture of alloys, corrosion inhibitory paints, wood preservatives, fixatives for dyes and tanning, photographic sensitizers and as anticorrosive in cooking systems and boilers (Cotman et al., 2004).

Table 5:Status of Chromium in the Drinking Water of Malwa Region of Punjab

\begin{tabular}{|c|c|c|c|c|c|c|c|}
\hline S.No & Districts & $\begin{array}{l}\text { Total } \\
\text { Samples }\end{array}$ & $\begin{array}{l}\text { No. of Unsafe } \\
\text { Samples }\end{array}$ & $\begin{array}{l}\text { \%age of Unsafe } \\
\text { Samples }\end{array}$ & Minimum & Maximum & Average \\
\hline 1 & Bathinda & 61 & 0 & 0 & 0.001 & 0.006 & 0.003 \\
\hline 2 & Muktsar & 36 & 36 & 100 & 1.8 & 3.6 & 2.690 \\
\hline 3 & Faridkot & 14 & 9 & 64 & 0.001 & 2.89 & 1.550 \\
\hline 4 & Ferozpur & 33 & 34 & 103 & 1.09 & 2.9 & 2.100 \\
\hline 5 & Moga & 48 & 21 & 44 & 0.001 & 2.3 & 0.520 \\
\hline 6 & Mansa & 28 & 28 & 100 & 0.054 & 2.3 & 1.030 \\
\hline 7 & Barnala & 10 & 0 & 0 & 0.001 & 0.004 & 0.002 \\
\hline 8 & Sangrur & 10 & 0 & 0 & 0.001 & 0.003 & 0.002 \\
\hline & Total & 240 & 128 & 53 & 0.001 & 3.6 & 0.987 \\
\hline
\end{tabular}




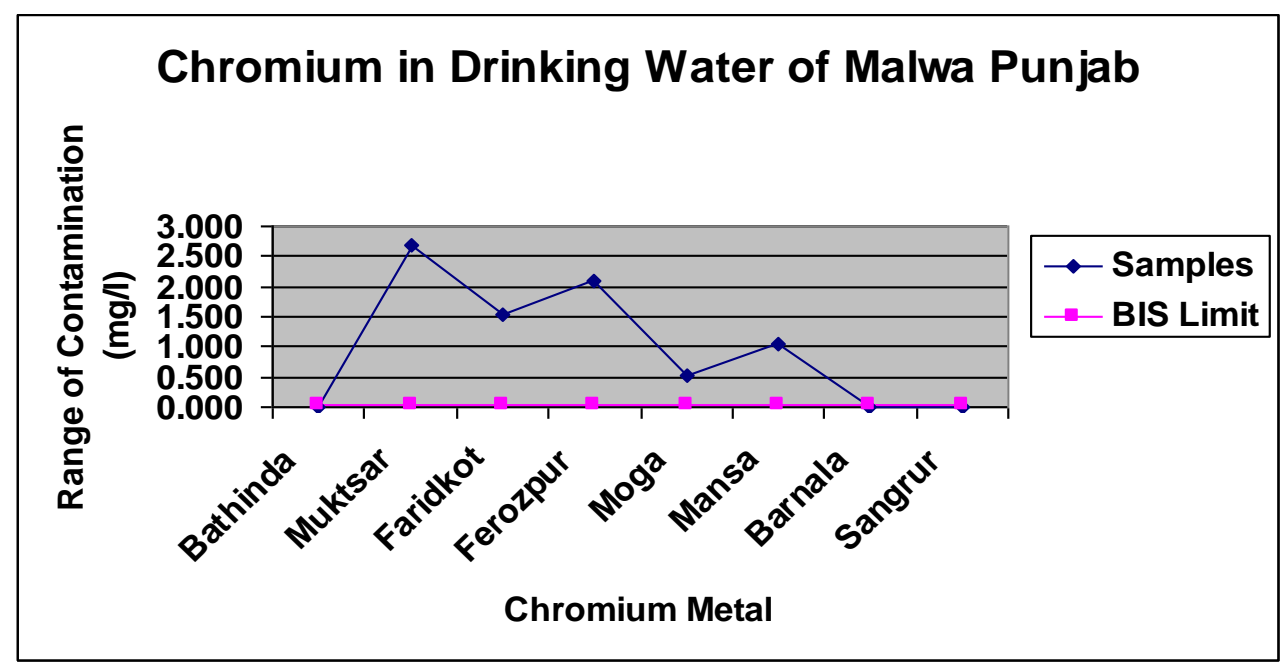

Figure 6: Chromium Contamination in Malwa Punjab

In the present study, the concentration of Chromium is ranges from $0.001 \mathrm{mg} / \mathrm{l}$ to $3.6 \mathrm{mg} / \mathrm{l}$ with an average of $0.99 \mathrm{mg} / \mathrm{l}$. Maximum values at Muktsar (3.6 mg/l) Ferozpur (2.9mg/l) > Faridkot (2.89 mg/l), Moga and Mansa $(2.3 \mathrm{mg} / \mathrm{l})>$ Bathinda (0.006 mg/l), Barnala $(0.004 \mathrm{mg} / \mathrm{l})$ while minimum at Sangrur $(0.003 \mathrm{mg} / \mathrm{l}$ but maximum contamination level of chromium in groundwater is $0.05 \mathrm{mg} / \mathrm{l}$, according to BIS. High concentrations of chromium are toxic, carcinogenic and teratogenic. $\mathrm{Cr}$ (IV) can enter the body when people breathe air, eat food or drink water. Certain Cr (IV) compounds have been found to be carcinogenic in humans, in particular into the lungs (Asmatullah et al., 1998). There is a wide variation in the $\mathrm{Cr}$ (VI) contents in groundwater samples throughout the Malwa region. The trivalent chromium appears to be important in the prevention of mild diabetes and atherosclerosis in humans (Towill et al., 1978).The hexavalent chromium at $10 \mathrm{mg} / \mathrm{kg}$ of body weight of humans will result in the liver necrosis, nephritis and death whereas the lower lower doses cause irritation of the gastrointestinal mucosa (Kaufman et al., 1970). Chromium is more important in rocks of a basic type than in those of silica type (Rodier et al., 1996). The toxicity of chromium depends on its physico-chemical shape; hexavalent salts are considered the most dangerous (Lauwerys et al., 1992). Results showed high concentration in the study area which indicates the anthropogenic input from the nearby electroplating, manufacturing and processing industries which may be as a result of untreated disposal, leakage due to poor-storing (Palmer Wittbrodt, 1991).

\section{-Mercury (Hg)}

Mercury is a metallic element that occurs naturally in the environment. Naturally occurring levels of mercury in groundwater and surface water are less than $0.5 \mathrm{mg} / \mathrm{l}$, although local mineral deposits may produce higher levels in groundwater. The level of mercury in fresh water bodies are less than $.0002 \mathrm{mg} / \mathrm{l}$ whereas levels upto $.03 \mathrm{mg} / \mathrm{l}$ have been reported in polluted rivers and lakes (Holden, 1972). In the present study, the concentration of mercury ranges from 0.001 to $0.27 \mathrm{mg} / \mathrm{L}$, with an average of $0.12 \mathrm{mg} / \mathrm{l}$. Whereas the maximum allowable limit for mercury as per BIS guidelines is $0.001 \mathrm{mg} / \mathrm{l}$. Maximum Concentration of mercury ware recorded at Muktsar and Moga $(0.27 \mathrm{mg} / \mathrm{l})$ followed by Bathinda, Faridkot and Ferozpur $(0.25$ $\mathrm{mg} / \mathrm{l})>$ Barnala and Sangrur $(0.21 \mathrm{mg} / \mathrm{l})>$ Mansa $(0.007 \mathrm{mg} / \mathrm{l})$. Acceptable limit of mercury is 0.001 $\mathrm{mg} / \mathrm{l}$ (BIS, 2004).

Mercury, toxicity results in mental disturbance and impairment of speech, hearing, vision and movement (Hammer and Hammer Jr., 2004). Chronic mercury poisoning results from exposure to small amounts of mercury over extended time period. Dramatic instances of toxicosis in human beings occurred in Japan (the Minamata disease), Iraq, Pakistan and Guatemala (D'Itri and D'Itri, 1977). The hydrological flushing of mercuryis likely due to the release of mercury accumulated from atmospheric deposition rather than from a geological source (Peckenham, 2003). If a level in drinking water of $0.5 \mathrm{mg} / \mathrm{l}$ is assumed, the average daily intake of inorganic mercury from this source would amount to about $1 \mathrm{mg}$. Mercury serves no beneficial physiological function in human beings. Each of its chemical states (metal itself, inorganic compounds and organomercurial compounds) has intrinsic properties that dictate independent toxicological assessment. Humic substances also may play a role in reducing ionic mercury to the elemental form in aqueous systems (Allard and Arsenie, 1991). 
Table 6: Status of Mercury in the Drinking Water of Malwa Region of Punjab.

\begin{tabular}{|c|c|c|c|c|c|c|c|}
\hline S.No & Districts & $\begin{array}{c}\text { Total } \\
\text { Samples }\end{array}$ & $\begin{array}{c}\text { No. of Unsafe } \\
\text { Samples }\end{array}$ & $\begin{array}{c}\text { \%age of Unsafe } \\
\text { Samples }\end{array}$ & Minimum & Maximum & Average \\
\hline & & & & & & & \\
\hline 1 & Bathinda & 61 & 54 & 89 & ND & 0.25 & 0.2 \\
\hline 2 & Muktsar & 36 & 36 & 100 & 0.12 & 0.27 & 0.2 \\
\hline 3 & Faridkot & 14 & 14 & 100 & 0.16 & 0.25 & 0.186 \\
\hline 4 & Ferozpur & 33 & 33 & 100 & 0.12 & 0.25 & 0.17 \\
\hline 5 & Moga & 48 & 48 & 100 & 0.12 & 0.27 & 0.21 \\
\hline 6 & Mansa & 28 & 25 & 89 & 0.001 & 0.007 & 0.003 \\
\hline 7 & Barnala & 10 & 6 & 60 & ND & 0.021 & 0.002 \\
\hline 8 & Sangrur & 10 & 7 & 70 & ND & 0.021 & 0.002 \\
\hline & Total & $\mathbf{2 4 0}$ & $\mathbf{2 2 3}$ & $\mathbf{9 3}$ & ND & $\mathbf{0 . 2 7}$ & $\mathbf{0 . 1 2 1 6 2 5}$ \\
\hline
\end{tabular}

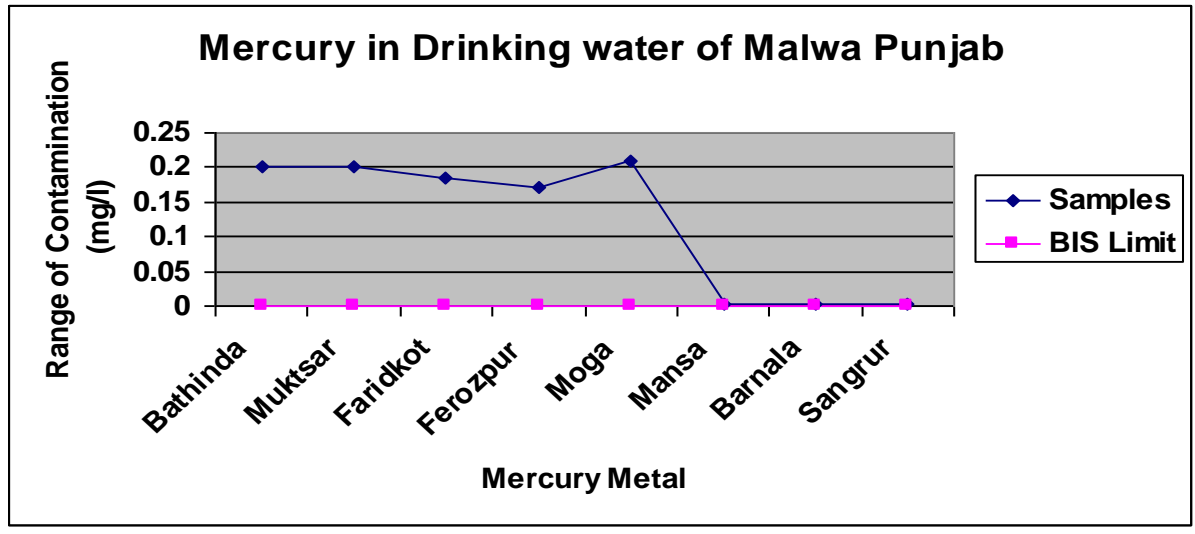

Figure 7: Mercury Contamination in Malwa Punjab

-Zinc (Zn)

Zinc is an essential element and is generally considered to be non-toxic below $5 \mathrm{mg} / \mathrm{l}$. Zinc is present in the drinking water, surface and ground waters in the range of 0.01 to $1 \mathrm{mg} / \mathrm{l}$. In the present study only $3 \%$ of the total samples ware found zinc beyond the permissible limit of $5 \mathrm{mg} / 1$ (BIS,2004). Tap water may contain higher concentration due to leaching fro the pipes (Legittimo et al.,1985; Schock and Neff,1988).High concentrations (150mg/l or more) mayresultin vomiying, dehydration, electrolyte imbalance, nausea, abdominal pain, lethargy, dizziness and lack of muscular co-ordination (Krishnan et al,1988). It is necessary for the functioning of the various enzyme systems including alkaline phosphate, carbonic anhydrase, alcohol dehydrogenase etc.(Parisic and Vallee, 1990.An endemic zinc deficiency syndrome, characterized by retarded growth and other signs of immaturity are probably by low intestinal absorption of zinc which can be cured by daily doses of zinc suplhate (Halsted et al., 1972). Maximum Concentration of Zinc were recorded at Muktsar $(21.5 \mathrm{mg} / \mathrm{l})$ followed by Moga $(4.0 \mathrm{mg} / \mathrm{l})$ $>$ Bathinda (1.99) > Ferozpur, Mansa (1.98 mg/l) > Barnala and Sangrur $(1.97 \mathrm{mg} / \mathrm{l})>$ Faridkot $(1.67$ $\mathrm{mg} / \mathrm{l}$ ). Acceptable limit of Zinc is $5 \mathrm{mg} / \mathrm{l}$ (BIS, 2004).

Table 7: Status of Zinc in the Drinking Water of Malwa Region of Punjab

\begin{tabular}{|c|c|c|c|c|c|c|c|}
\hline S.No & Districts & $\begin{array}{l}\text { Total } \\
\text { Samples }\end{array}$ & $\begin{array}{l}\text { No. of Unsafe } \\
\text { Samples }\end{array}$ & $\begin{array}{l}\text { \%age of Unsafe } \\
\text { Samples }\end{array}$ & Minimum & Maximum & Average \\
\hline 1 & Bathinda & 61 & 0 & 0 & 0.025 & 1.99 & 0.99 \\
\hline 2 & Muktsar & 36 & 11 & 31 & 0.025 & 21.5 & 5.64 \\
\hline 3 & Faridkot & 14 & 0 & 0 & 0.005 & 1.67 & 0.52 \\
\hline 4 & Ferozpur & 33 & 0 & 0 & 0.025 & 1.98 & 0.92 \\
\hline 5 & Moga & 48 & 0 & 0 & 1.2 & 4 & 2.73 \\
\hline 6 & Mansa & 28 & 0 & 0 & 0.025 & 1.98 & 1.03 \\
\hline 7 & Barnala & 10 & 0 & 0 & 0.03 & 1.97 & 0.84 \\
\hline 8 & Sangrur & 10 & 0 & 0 & 0.03 & 1.97 & 1.17 \\
\hline & Total & 240 & 11 & 5 & 0.005 & 21.5 & 1.73 \\
\hline
\end{tabular}




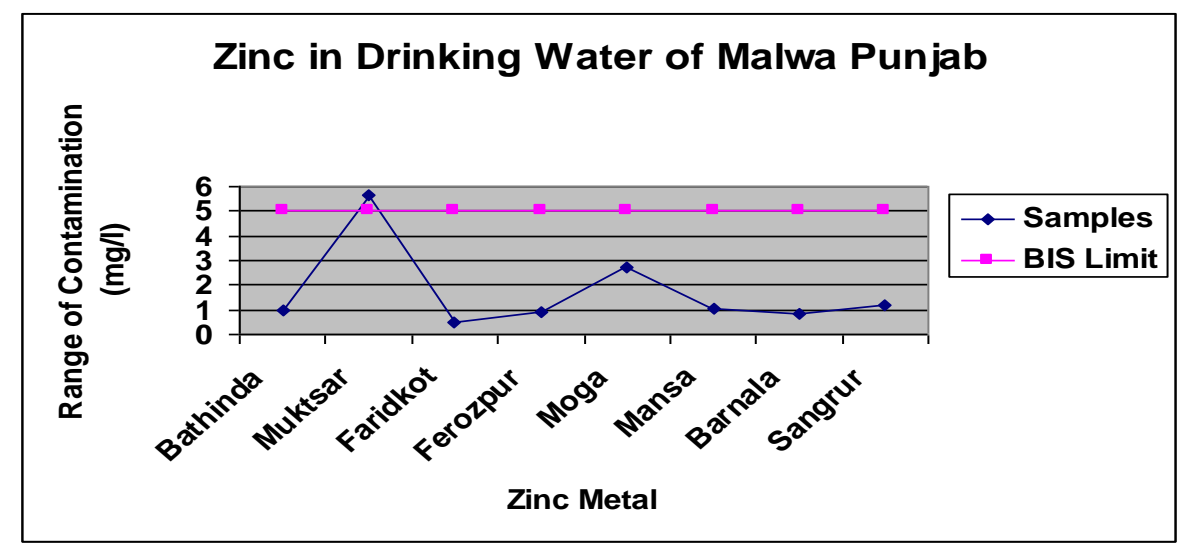

Figure 8: Zinc Contamination in Malwa Punjab

\section{CONCLUSION}

Overall, the quite higher concentrations observed in ground water samples of the SWPunjab region may be due to local natural geology, industrial activities in the region or use of phosphate fertilizers in the region in huge quantity for agricultural purpose as the region is well known for it or due to any other human activities (Tripathi et al., 2013).

For the first time, eight districts having different heavy metals were determined under this project by using Atomic Absorption spectrophotometer. Groundwater sources/locations have been found more contaminated lying in the dense population areas. A different pattern of results presentation is adopted on district level basis instead of parameters, which is more appropriate and easy in understanding for policy makers, district municipal community and water supply managers to adopt future line of actions.

\section{RECOMMENDATIONS}

Water treatment plants in villages are based on the antiquated sand filtration system. The state government needs to invest heavily into water treatment to avoid a potential disastrous situation. A state wide awareness campaign is needed to convince farmers of the deleterious affects of excessive pesticide usage to avoid a potential disastrous situation. Agriculture fires should be banned in all over the India after harvesting the fields to prevent the groundwater pollution.

\section{REFERENCES}

[1]. Abernathy, C.O., Marcus, W., Chen, C., Gibb, H., Write, P., 1989.Report on Arsenic Work group Meeting, Office of Drinking Water, Office of Research and Development, USEPA, Memorandum to P. Cork, P. Preuss. Office of Regulatory Supportand Scientific Management, USEPA.
[2]. Allard, B., Arsenie, I.,1991. Abiotic reduction of mercury by humic substances in aquatic system-an important process for the mercury cycle. Water, Air, Soil Pollut. 56, 457-464.

[3]. Anderson, A.R., Polansky, M.M., Bryden, N.A., Roginski, E.E., Mertz, W. and W. Glinsmam (1983). Chromium supple mentation of human subjects: Effects on glucose,insulin and lipid variable.Metabolism, 32, 894-899.

[4]. Anderson, R.A. (1988). Effects of chromiumon body composition and weight loss.Nutr. Rev., 56, 266-270.

[5]. APHA, AWWA, WEF, 1998. Standard methods for examination of water and waste water, 20 ${ }^{\text {th }}$ Ed. American Public Health Association, Washington, DC.

[6]. Asmatullah, S., Quershi, N.\& A.R., Shakoori (1998). Embryotoxic and tetraogenic effects of hexavalent chromium in developing chicks of Gallus domesticus. Bull. Environ. Contom. Toxicol., 61,281288.

[7]. Bureau of Indian Standards (BIS), 2012. Indian standard specification for drinking water. New Delhi, India. BIS publication No. IS: 10500.

[8]. BIS (Bureau of Indian Standard),(2004-05), Indian standard specification for drinking water.New Delhi, India. BIS publication No. IS: 10500 .

[9]. Calder, L.M.,1988.Chromium Contamination of Groundwater. IN: Chromium in the Natural and Human Environments, Vol. 20 (J.O.Nriagu and E. Nieboer, editors).John Wiley and Sons, New York: 215-230.

[10]. Cerbrian, M.E., Albores, A., Aquilar, M., Blakely, E., 1983. Chronic arsenic poisoning in thenorth of Mexico. Human Toxicol. 2, 121-133. 
[11]. Chakraborty, A.K., Saha, K.C., 1987. Arsenical dermatosis from tubewell water in West Bengal. Ind. J. Med. Res. 85, 326-334.

[12]. Christensen T.H., Kjeldsen P., Bjerg P.L., Jensen D.L., Christensen J.B.and Baun A. (2001), Biogeochemistry of landfill leachate plumes. Applied Geochemistry.(16), 659718.

[13]. Cotman, M., Zagorc-Koncan, J. \& A.ZgjnarGotvajn. 182 Antonia Moraki Project 35: 17 2/14/11 9:00pm Page 182 (2004).The relationship between composition and toxicity of tannery wastewater.Water Sci. Tech., 49 (1), 39-46.

[14]. CPCB (Central Pollution Control Board), 2001. Water quality status of lacks and reservoirs in Delhi. Report.

[15]. D'Itri P.A., and F.M. D'Itri, “ Mercury Contamination- A Human Tragedy “,John Wiley \& Sons,New York, 1977.

[16]. Drever J.I. (1997), The geochemistry of natural water, $3^{\text {rd }}$ edition. Prentice hall, New Jersey, pp 436.

[17]. Environmental Protection agency (EPA), 2007. Framework for Metals Risk Assessment ; EPA 120/R-07/001.

[18]. European Commision Report (2002), Heavy metals in waste (final report),European Commision DG ENV. E3 Project ENV.E3/ETu/2000/0058, Denmark.

[19]. Halsted, J.et al., (1972). Zinc deficiency in man, Am. J. Med., 53,277-284.

[20]. Hammer, M.J., and M.J. Hammer, Jr., 2004.Water Quality. In: Water and Waste Water Technology. $5^{\text {th }}$ Edn. New Jersey: Prentice-Hall,pp: 139-159.

[21]. Hindmarsh, J.T., McLetchie, O.R., Heffernan,L.P.M., Hayne, O.A., Ellenberger, H.A., McCurdy, R.F., Thiebaux, H.G., 1977. Electromyographic abnormalities in chronic environmental arsenicalism. J. Anal. Toxicol. 1, 270-276.

[22]. Holden, A.V.and R.Lloyd, (1972).Symposium on the nature and extent of water pollution problems affecting inland fisheries in Europe, EIFAC technical paper no. 16. Rome: FAO.

[23]. Huang, W. H.; Poynton, C.Y.; Kochain,L. V.; andElless, M. P.2004, Environ. Sci. Technol. 38: 3412-3417.

[24]. Hughes, M.F.2002.arsenic toxicity and potential mechanism of action. 1-6 In. Toxicilogy letters. Vol.133.

[25]. Hundal H, Singh K, Singh D. Arsenic content in ground and canal water of Punjab, North-West India. Environ Monit Assess. 2009;154:pp.393-400.
[26]. Jain C. K., Bandyopadhyay A. and Bhadra A. (2010), Assessment of groundwater quality for drinking purpose, District Nainital, Uttarakhand, India. Environmental Monitor. Asses. 166 (1-4), 663-676.

[27]. Jarup, L. Hazards of heavy metal contamination. Br. Med. Bull. 2003, 68, 167182.

[28]. Kaufman, DB et al (1970), American J. of Diseases of Children, 374:119.

[29]. Krishnan S.S., D.R. McLachlan, A.J. Dalton, B. Krishnan, S.A. Fenton, J.E. Harrison and T. Kruck," Aluminium Toxicity in Humans, Essential and Toxic Trace Elements in Human Health and Diseases", Alan R. Liss., New York, 1988.

[30]. Lauwerys,

$\mathrm{R}$. (1992).Toxicologieindustrielleet intoxications professionnelles, 3e edition, Masson,Paris, France, 693 p.

[31]. Legittimo P.C., L. Ghilardini and F. Pantani, Riv. Ital. Ig., 1985, 45,1.

[32]. Nimick, D.A.1994. Arsenic transport in surface and ground water in the Madison and upper Missouri River Valleys, Montana.American Geophysical Union Fall Meeting, 247.

[33]. Nriagu, J.O., 1988b.Production and Uses of Chromium.IN: Chromium in the Natural and Human Environments, Vol.20 (J.O. Nriagu and E. Nieboer, editors).john Wiley \& Sons, New York: 81-104.

[34]. Palmer C.D.and Wittbrodt P.R.(1991), Processes affecting the remediation of chromium contaminated sites. Environ. Health Perspectives. (92), 25-40.

[35]. Parisic A.F.and B.L.Vallee, American Journalof Clinical Nutrition, 1969, 22,1222.

[36]. Peckenham, J.M., Kahl, J. S.,Mower, B. Background mercury concentrations in river water in Maine, U.S.A. Environ. Monit. Assess. 89,129, 2003.

[37]. Pickering, I. J.; Prince, R. C.; George, M.J.; Smith, R .D.; George, G . N.; and Salt, D. E.2000. Reduction and coordination of Arsenic in Indian Mustard. Plant Physiology. 126: 1171-1177.

[38]. Raju, N.J., Ram, P., \& Dey, S.(2009).Groundwat Qualityin the Lower Varuna River Basin, Varanasi District, Uttar Pradesh Journalof the Geological Society of India, 73(2), 178-192.

[39]. Rodier, J., Bazin, C., Broutin, J.P., Chambon, P.,Champsaur, H., Rodi,L. (1996). L'analyse de I'eau: eauxnaturelles, eauxresiduaires, eaux de mer.Paris: Dunod, 8e ed.; 1, 383p. 
[40]. R.M. Tripathi, S.K. Sahoo, S. Mohapatra, P. Lenka, J.S. Dubey, V.D. Puranik Study of uranium isotopic composition in groundwater and deviation from secular equilibrium condition Journal of Radioanalytical and Nuclear Chemistry, 295 (2013), pp. 1195-1200.

[41]. Roychowdhury, T., 2008a. Impact of sedimentary arsenic through irrigated groundwater on soil, plant, crops and human continuum from Bengal delta: special reference to raw and cooked rice. Food Chem. Toxicol. 43, 2856-2864.

[42]. Roychowdhury, T., Uchino, T., Tokunaga, H., Ando, M., 2002b. Survey of arsenic in food composites from an arsenic- affected ares of west Bengal,India. Food Chem. Toxicol.40, 1611-1621.

[43]. Sarkar, B. Heavy Metals in the Environment; CRC Press: New York, NY, USA, 2002.

[44]. Schock MR, Neff CH. 1988.Trace metal contamination from brass fittings. J. Am. Waterworks Assoc. 80: 47-56.

[45]. Towill LE et al. (1978), Review of the environment effects of pollutants, III chromium, Cincinnati, US Dept.of Commerce, NationalTechnical Information Service (PB-282-796).

[46]. USEPA, United States Environmental Protection Agency (2004).

[47]. U.S. Environmental Protection Agency, 1999. Special Report on Ingested Inorganic Arsenic Skin Cancer: Nutritional essentiality In. Report EPA/625. 3-87-13.

[48]. Vincet, J.B. (2000). The biochemistry of chromium.J.Nutr., 130, 715-718.

[49]. WHO. (2004). Guidelines for drinking water Quality. Geneva.

[50]. WHO, 2005. International Standards for Drinking Water. Water Sciences and Society, Curr: Sci., 89 (5), pp. 787-793. World Health Organization, Geneva, (1971). 